\title{
Museums and Memories: Remembering the Past in Local and Community Museums $^{1}$
}

\author{
JANIS WILTON
}

Public History Review, vol 12, 2006, pp58-79

\begin{abstract}
T here is a range of memories which are created and promoted through museums: the memories of the past conjured by curators, the national memories peddled by politicians, the memories contested by communities, the memories of museum visits collected by museum visitors and the memories and memorialising of collectors and their collections. These memories jostle for space within museums and within the growing literature about museums. They flow into broader studies about the relationship between memory and history and about the role of memory in cultural studies. They underpin debates about what should be presented in museums. They highlight aspects of the changes underway in the world of museums. ${ }^{2}$

This article explores a selection of these memories and the issues they raise. It begins with the tensions and innovations created as curators, communities and critics increasingly seek to control or at least share the power to select and interpret the memories presented in museums. It then looks at the ways in which the memories and memorialising of founding collectors, their collections and museum practices influence the shape and tone of museums. Finally, attention turns to the memorable museum moments which visitors take with them and the extent to which these moments are edging museums in different directions.

The emphasis throughout is not on the large and relatively well resourced state and national institutions. These provide counterpoints. Rather, the examples used come primarily from much younger local and community museums whose existence depends so much on the people and places whose (hi)stories they tell.
\end{abstract}

\section{CURATORS, COMMUNITIES AND CRITICS}

In the new museology of the late twentieth and early twenty-first centuries much attention is being paid to the roles of curators, communities and critics in creating and debating the memories and messages displayed in museums. Incisive critiques expose the bias and embedded views which can be read in the way 
objects are collected and exhibited, the labels and publications which add textual messages to the sensory experiences and the purpose of a museum itself. ${ }^{3}$ National museums attract particular commentary. They are seen as sites of national remembering, as places where the nation's narratives are put on display and invite a reinforcement of national values and ideals. They are also increasingly sites of debates about whose memories and whose histories should dominate. ${ }^{4}$ This is only too well illustrated by the recent controversy which focuses on the National Museum of Australia. ${ }^{5}$ It is a debate among mainly white historians and their political backers about which version of Australia's history should be honoured with public remembering. The debate acknowledges and demonstrates the role of museums - along with monuments, celebrations, films, art, buildings - in national remembering, in those attempts to create and promote narratives which give a sense of what it was and is to be Australian. The criticism of the National Museum turns on a concern that it overemphasises - or, if Keith Windschuttle is to be believed, inaccurately documents - the dark side of Australia's past. For these critics the desire is to present a grand narrative which offers a sense of achievement and progress. In many ways, it is a very simple, two-dimensional view, inviting those of us who are onlookers to align ourselves with one side or the other. It does, however, graphically highlight the public and political significance given to the place of museums and the memories they represent.

While acknowledging the power and significance of this debate around national remembering, my focus here is on other more individual, local and community memories and their place in museums. As former University of New England academic Tessa Morris-Suzuki wrote in a very evocative article describing a visit to the museums and memories of what is now the Russian island of Sakhalin, formerly the Japanese colony of Karafuto:

It is necessary to continue the contest over the shape and meaning that is given to national and global pasts. But I think that it is important to leave room for the smaller histories, in which regional, minority and individual rememberings are allowed space to grow in all their complexity and ambiguity. ${ }^{6}$

In this vein, I propose to take you on visits to a small number of museums which offer illustrations of the ambiguities and complexities of the ways in which they remember the past and of the ways in which their communities, critics and museum professionals engage with and contest those memories.

\section{THE 'GOLDEN THREADS' PROJECT}

Over the past five years, I have been engaged in a publicly funded project entitled 'Golden Threads'. Its primary objective has been to work with local museums in parts of regional New South Wales to identify and document objects in their collections which provide evidence of the Chinese presence in particular 
localities. ${ }^{7}$ When first approached, the staff of some museums declared an absence of such objects though a willingness to include them while others directed us to a variety of objects. The nature of those objects identified as relating to the Chinese presence is significant. In some museums, the objects were clearly provenanced and carried labels which correctly identified the objects, their uses and, occasionally, stories associated with them. In a number of museums, however, objects were incorrectly identified: a soy sauce brownware jar labelled a Ming vase, an opium tin described as a container for returning the ashes of the deceased to China, a mortar as an incense burner, a tobacco water pipe as an opium pipe. Similar mislabelling has been identified among collections in local museums in California, that other region where gold rushes brought a significant Chinese presence. ${ }^{8}$ The advice from California - and presumably from all historians and museum professionals heavily imbued with an empiricist sense and an emphasis on getting the information correct - is that the museums who are the new owners and keepers of these objects need to be better informed and the information on the labels altered.

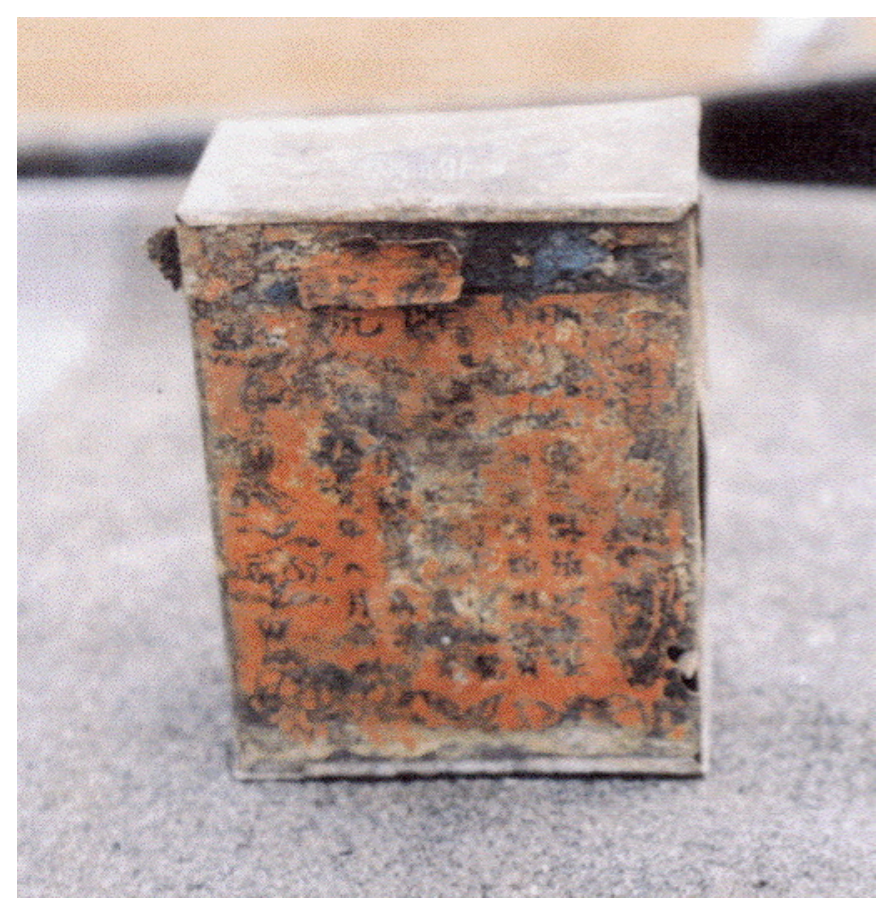

Opium container from around the turn of the twentieth century, found On the Sofala goldfields (Private collection)

Obviously, there is a need to provide and present the corrected information. But it is also important to retain the original labels and identifications. They offer evidence and documentation of the complexities of the memories which surround the Chinese presence and contribution to particular localities. Here I borrow from the work of oral historian Alessandro Portelli and his significant contributions to our understanding and analysis of the collective mistakes made when recalling particular events or experiences from the past. ${ }^{9}$ Portelli's seminal article 
concerned a collective mistake made about the timing of the death of an industrial worker in the northern Italian town of Terni after the Second World War. Rather than discarding his oral history interviews as invalid and unreliable because they contained this mistake, Portelli asked: What does the mistake tell us about the significance of events in the past? If this is applied to the mistakes made in remembering the Chinese presence as represented in the (mis)labelling of particular objects in museum collections, what we learn is that the current custodians of these objects - the staff and volunteers at local museums - are conveying long held local attitudes and views of the Chinese presence.

The Chinese were a part of the locality's history and objects documenting their presence were readily included in collections which swept into the museum anything and everything relating to that place. The Chinese, however, were an exotic presence and were seen to have strange and different habits. They were there as service providers - particularly market gardeners and storekeepers and were appreciated for this but they were outsiders about whom there were stereotypes which subsequently entered into the oral traditions of the local community. These oral traditions resurface in object labels. The soy sauce container is known to be Chinese but, with no knowledge of its function, it is labelled with an overtly Chinese description - a Ming vase. Chinese were known to smoke opium - local press and memories are rife with this as one of their habits - and consequently any oriental or exotic-looking pipe represents this habit. There were Chinese temples, known as 'joss houses', throughout regional New South Wales. They are remembered as exotic places with incense burning, bright colours, savage faced gods. So an object which came from the building known to have once been the local Chinese community's temple is understandably labelled as an incense burner. The mistakes are evidence of the complexities of remembering. To discard the mistakes is to discard evidence of the presence and place of Chinese immigrants in the imaginings and memories of local European residents. To leave them without correction and without complementing them with memories which locate the real functions and uses of the objects is to affirm stereotypes and misremembering. ${ }^{10}$

Are there solutions? Are there ways of representing both memories and, indeed, other memories - of acknowledging and representing complexities? There are examples. As museums in the late twentieth and early twenty-first centuries have recognised the need to represent different voices and memories, they are developing strategies to incorporate these layered perspectives. Early examples for me were encountered in a visit to New York in 1994 and in a visit in 2002 to the District Six Museum in Cape Town, South Africa.

\section{The National Museum of the American Indian}

During the visit to New York and among visits to many museums, two were particularly memorable for the ways in which they presented alternative narratives and memories. The New York site of the National Museum of the American Indian opened while I was there. ${ }^{11}$ Its three inaugural exhibitions overtly sought to 
incorporate native American perspectives and voices. As the Museum's director, Richard West, stated at the time:

although the material basis of the museum is the magnificent onemillion-piece Heye Collection, ${ }^{12}$ ours will be an institution that explores not just objects, but the people and cultures who created, and are still creating, those objects. ${ }^{13}$

The museum wanted to demonstrate its sound research and curatorial base and combine this with the insights offered from native Americans. Strategies included labels which offered at least three different perspectives on an object - those of a curator, an anthropologist and a native American; an exhibition of objects selected, curated and explained by native Americans; and an exhibition by contemporary native American artists exploring and expressing their responses to the world around them. 


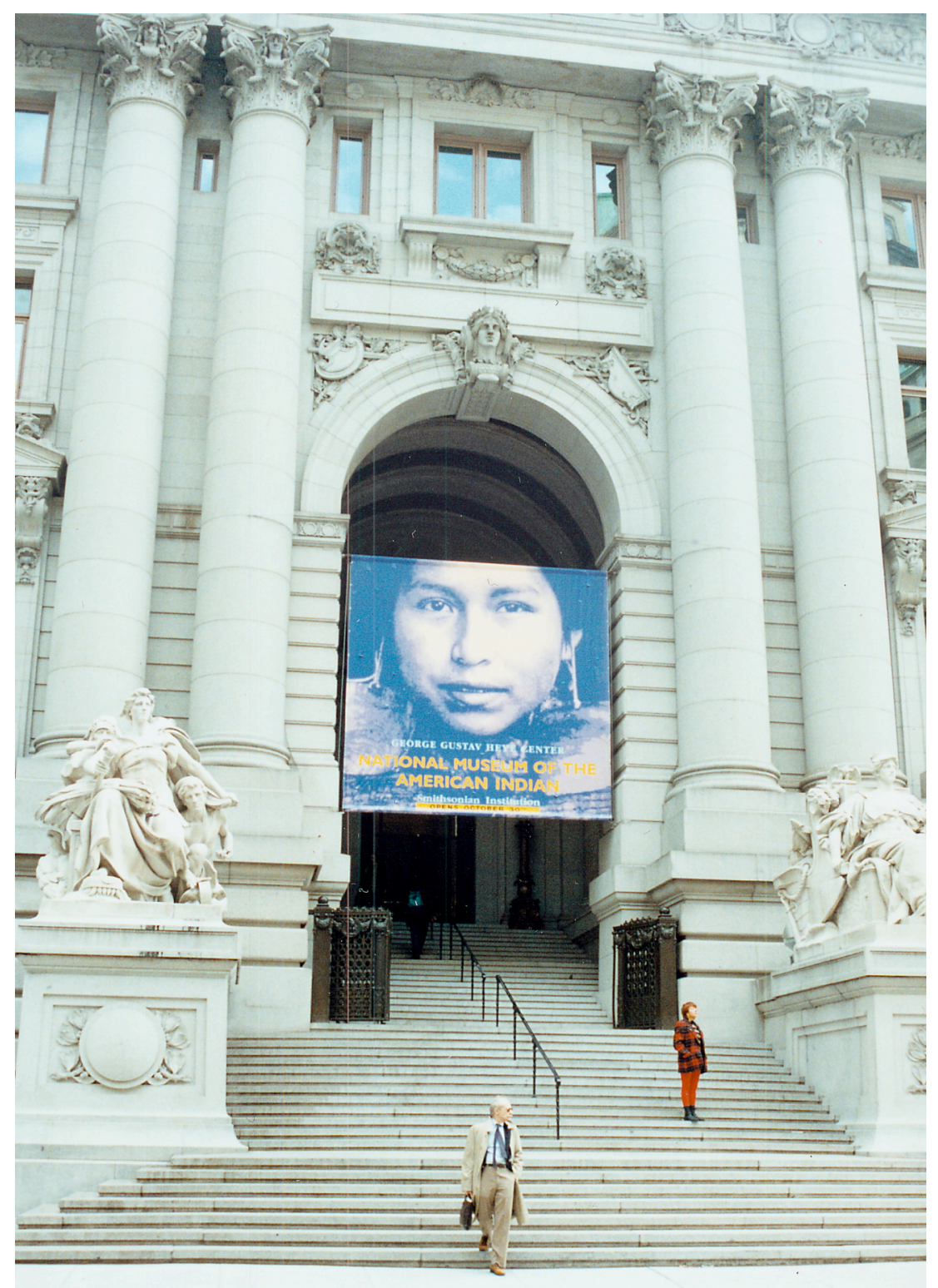

The National Museum of the American Indian 1994 (Photograph Janis Wilton)

The objects were there but so were video and audio clips, dioramas, art installations. There were competing sounds. The messages, however, were clear: the voices of native Americans were overtly challenging, confronting and complementing traditional curatorial expertise. In particular, they were questioning the very essence of a museum's existence: the notion that objects in and for themselves can be collected and presented as precious objects and that there is a single curatorial explanation which records their significance.

Multimedia artist Conrad House (Navajo/Oneida) explained this from the Navajo perspective: 
In the concepts of the traditional people, in our language, there is not a word for art. If there was a word for art, then yes, all this is art. What you do and how you live in this world is called hoisjorgo, going about this world in beauty... How you live, every little thing you do, the way you cook, how you arrange your home - in the Navajo way this would all be like art. ${ }^{14}$

The experience was too much for some museum reviewers at the time. One, while acknowledging the importance of what the museum was attempting to achieve and praising the significance of its collection, wrote in exasperation condemning the inaugural exhibitions. He criticised the

smorgasbord of display devices... ranging from sound-and-light video presentations to piped-in sound tracks, to dioramas and architectural motifs, to wall texts that play down hard information in favour of interpretive glosses drawn largely from myths and oral traditions. ${ }^{15}$

Here was a reviewer who, like some engaged in the recent debates about the National Museum of Australia, has an empiricist and elitist view which allows no credit for the nuances of oral sources and memory, nor for the increasingly sophisticated ways in which those sources and memories can be read.

\section{MUSEUM FOR AfRICAN ART}

Elsewhere in New York, the Museum for African Art took these challenges a step further. ${ }^{16}$ In an exhibition entitled Exhibition-ism, the museum confronted visitors with the processes involved in creating an exhibition and used its exhibited objects to argue that western museum practices contradict the ways in which art and artifacts are used and understood among African communities. Criticised by one reviewer for its 'preachy didacticism' and for having 'a little of the feeling of a lecture illustrated by actual objects rather than slides', ${ }^{17}$ two strategies were memorable for me. 


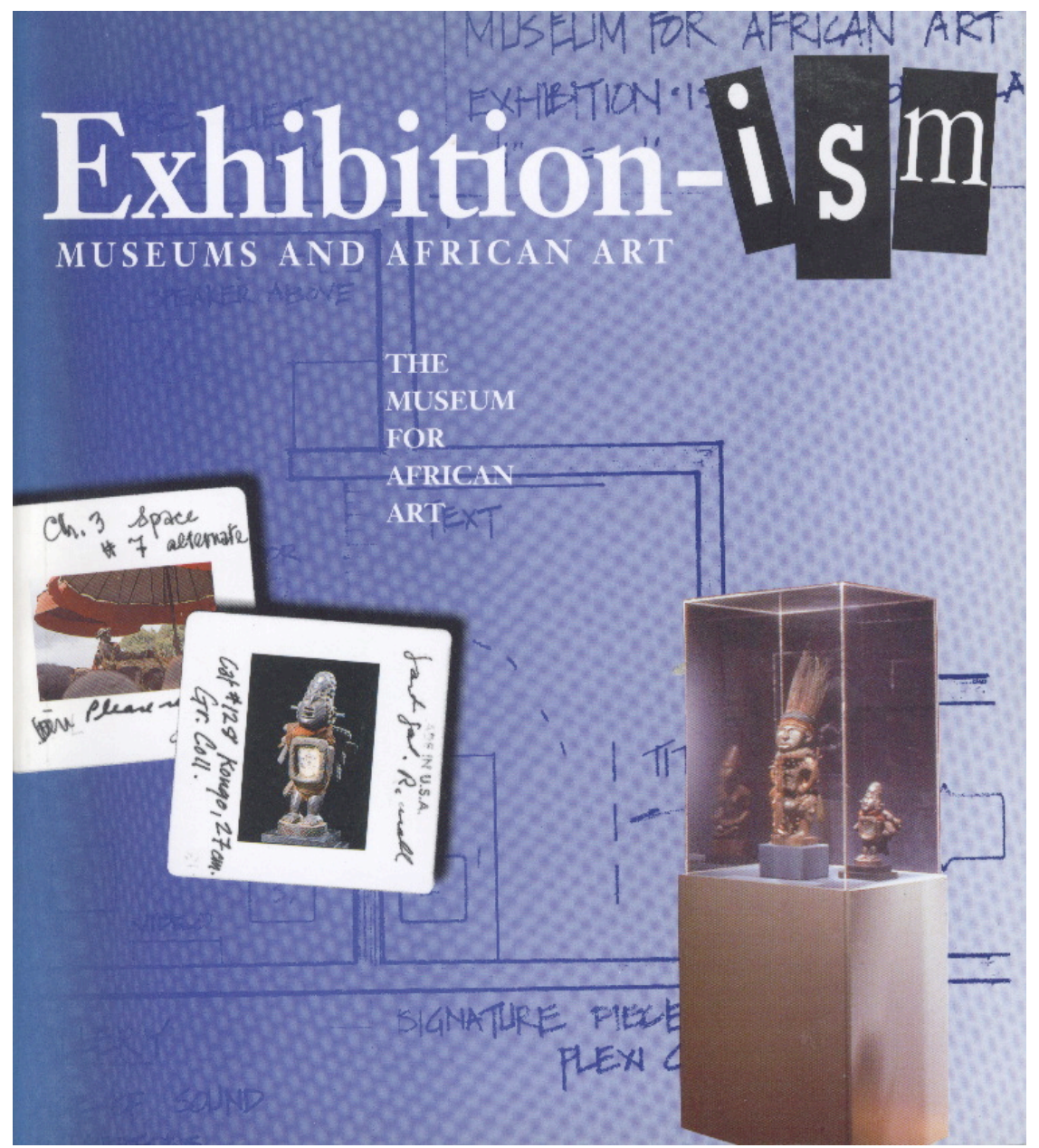

Front cover of the catalogue for Exhibition-ism, Museum for African Art, 1994

The first was a room containing about a dozen quite beautiful masks and figurative sculptures, each in its own perspex display case and looking at first glance like a traditional museum exhibition. On closer examination, there were two sides to each display case. From one side, there was a view of the front of the mask or sculpture and a traditional museum label - 'Mask. Lega, Zaire.

Wood, fiber. Early twentieth century. Private collection.' On the reverse side, however, could be viewed, for example, the inside of the mask as it was seen and viewed by the wearer of the mask, the supports used to display the object, and labels with a variety of messages: disagreements about the authenticity or use of a particular object, discussions about how the object was acquired or misappropriated, details of the cost of the display. The museum was subverting its own practices and stating overtly - and perhaps didactically - that any one object on display is supported and contested by a variety of experiences, stories and memories.

The second aspect of Exhibition-ism which remains with me is the final room: not memorable for the way it looked or, indeed, for the objects in it but for the idea behind it. The objects in this room were made available for a range of invited 
visitors to offer suggestions about display, labels, organization. Throughout the life of the exhibition, the suggestions made saw changes in this room: the same objects were arranged, rearranged, displayed differently, interpreted differently. This was an overt statement about the changing meanings which can be associated with objects dependent on the way they are collected and presented. And it was an overt statement that museum visitors have different visions and expectations - they are not necessarily passive onlookers waiting to have their minds and memories filled with the expert knowledge and stories passed on by curators.

\section{DISTRICT SIX MUSEUM}

The vitality and significance of involving museum visitors as an integral part of the museum experience was highlighted again for me when I visited the District Six Museum in Cape Town in South Africa in 2002. Here community memories brought by visitors to the museum are incorporated into the museum's exhibitions. Indeed, it is these memories which provide the focus and key material in the museum.

Established in 1994, the museum is a product of post-apartheid South Africa and, as such, sits within the grand narrative about the horrors of apartheid and the need for reconciliation which dominate nation-building in the new South Africa. Yet, within this narrative, the museum invites individual and local voices and memories. Here is a museum established by and for a community of people bound together by their expulsion during the apartheid regime from the locality in which they lived. ${ }^{18}$ The exhibitions in the museum grow primarily around previous residents of District Six visiting, adding their names to the street map which occupies the floor of the museum, adding their oral histories, photographs and memorabilia to the collections and seeing those memories reconstructed around objects, places and voices.

The emphasis is on recreating the normality of life in the district before its demolition and the forced separation of its residents. This is achieved not simply by attaching labels to objects but by recreating rooms and the sounds and smells of those rooms, the voices and stories reverberating around the walls. There is a hairdresser's salon from the 1950s with its pink walls, plastic flowers and hairstyling paraphernalia. There is a reconstruction of the room which was home for Nomvuyo Ngcelwane at 21 Cross Street. From the radiogram in the room come memories of mealtimes, family relations, furniture and the sounds of a popular song from the time. Past residents and tourists also have their visitors' messages - and their memories - stitched into calico cloths which themselves become a part of the museum experience. For returning residents and for visitors with no previous knowledge of the history of the neighbourhood, this is an encounter with the complexities of the individual memories which resonate around the locality.

The message inscribed at the entrance to the museum when it opened after refurbishment in 2000 emphasises the desire to include the good and the bad, 


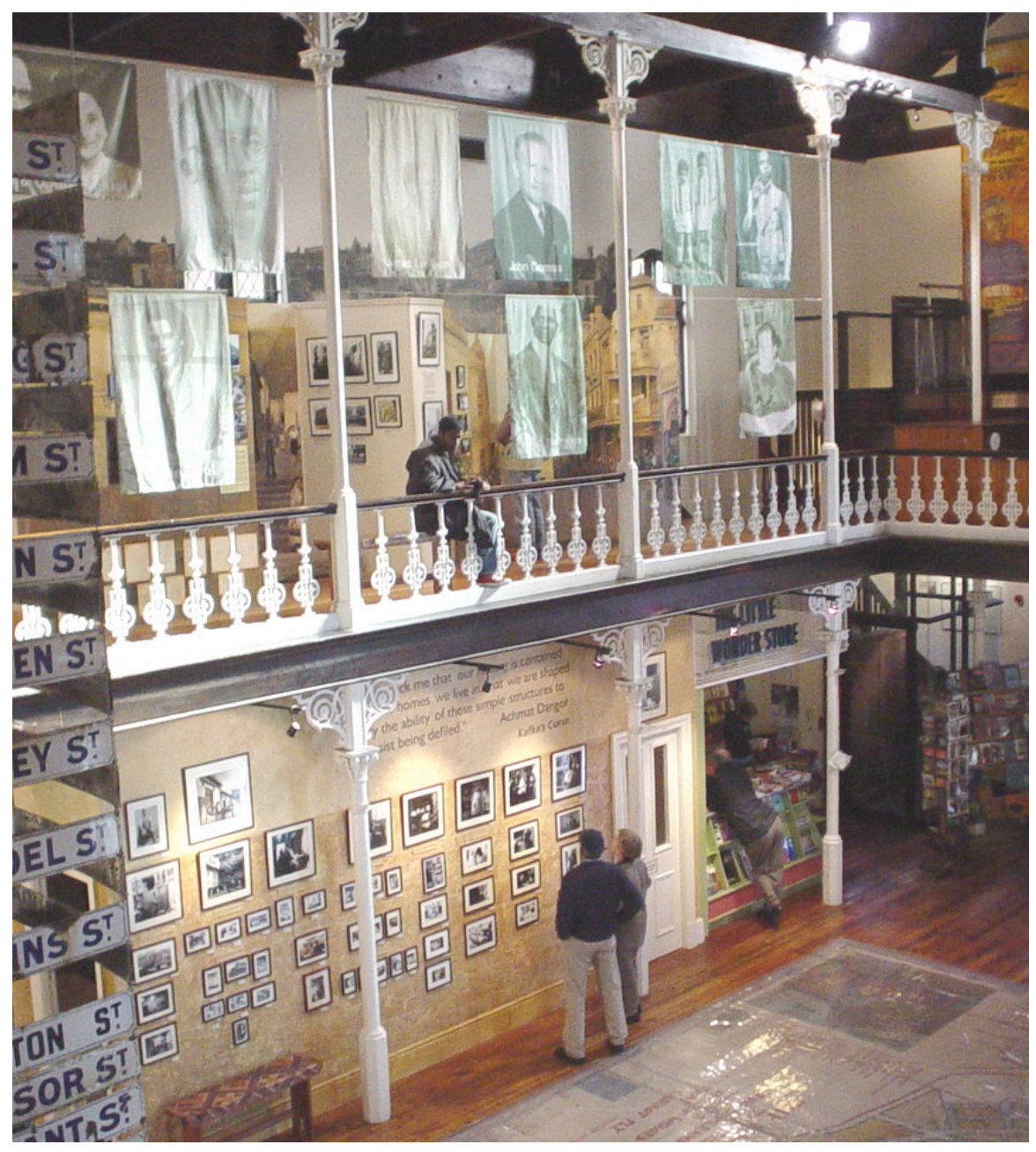

Main hall of the District Six Museum, Cape Town, 2002 (Photograph Janis Wilton)

the harmonies and the disharmonies but, above all, to emphasise that preapartheid District Six was a place in which people from different cultural and religious backgrounds managed to live together. It inscribes a message of defiance about the narratives created by apartheid and highlights that the future being sought for the new South Africa had worked in the past. ${ }^{19}$ Importantly, also, this is a message inscribed by South Africans who are not all supporters of the ANC version of the new South Africa. This, after all, was a 'coloured' district in Cape Town, not a black district. The overriding narrative here is certainly different to that encountered in the government-sponsored museums of the new South Africa - the Apartheid Museum in Johannesburg or the Robben Island Museum. The messages there are primarily about the brutality of apartheid and the achievements of the ANC. District Six offers a different community emphasis with a complexity of voices and memories. 


\section{Wing Hing Long STORE Museum}

The District Six Museum provides a powerful example of how local memories and local ownership can create and control the messages in a museum. There is an example - although quite different and certainly not nearly as well developed - of this closer to home in the Wing Hing Long Store Museum in Tingha in northern New South Wales.

Wing Hing Long emerged as a community managed museum in the late 1990s. It was a product of the coming together of a variety of factors and forces. And its history and the memories which it presents and evokes provide a good example of the different individual and community memories and expectations which can echo around a local museum in regional New South Wales.

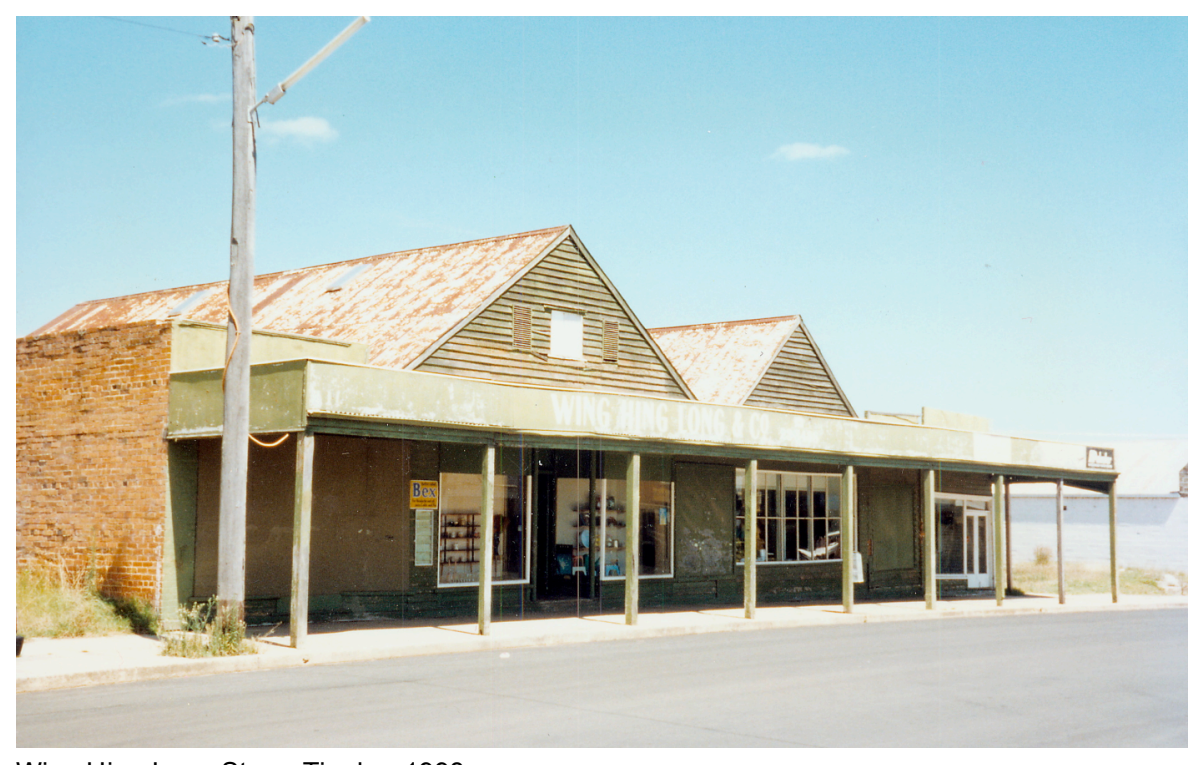

Wing Hing Long Store, Tingha, 1998

The Wing Hing Long store had serviced the Tingha community as a general store from the 1880s until the late twentieth century. Throughout its history it remained in the ownership and management of Chinese-Australians, in particular the family of Jack Joe Lowe. In the late 1990s, J.J. Lowe's daughter, Mavis Pratt, decided it was time to retire and to sell off the business. She was nearly eighty. The store itself was not a viable business. Tingha had been in significant economic decline for some time. Her timing was serendipidous. The state government had directed its cultural organisations to be active in regional areas and to spend more time and resources in engaging and documenting the state's cultural diversity. Members of the local community were forming a small visitors' centre which housed and displayed photographs and objects relating to the locality's history. And the Golden Threads project was on the road. The end result saw the NSW Heritage Office purchase Wing Hing Long and its contents, transfer the ownership to the local Guyra Shire Council and place the management of the museum in the hands of a group of Tingha residents. ${ }^{20}$ 
From the start, there were different views about whose memories and stories should set the tone of the new museum. ${ }^{21}$ From within the community were those who wanted the focus to include the role of tin mining in the history of the locality and to collect objects about tin mining, others wanted a significant part of the store devoted to displaying and selling local arts and crafts, others - including the NSW Heritage Office - wanted an emphasis on the store itself and its ChineseAustralian ownership. Some wanted the store renovated, others saw the benefits in stabilising the store in the state it was in at the time of its change of ownership. These different views and debates have shaped the store as it can be experienced today and, indeed, after initial attempts to impose particular views, the variety of memories and stories are what makes the museum come alive. There are arts and crafts for sale and splendid morning and afternoon teas. There is a significant photographic collection documenting the history of tin mining and much more in the locality. There are details, memories and some folklore - akin to the mislabelled Chinese objects identified in museums across the state - about the owners of the store, Chinese and non-Chinese employees and about the store itself. There are different accounts of what it was like to work in the store and the personalities who worked there. Two opposing memories serve as an example.

Arthur Gar-Lock Chang, a respected member of the Chinese community in Sydney, was originally sponsored to come to Australia in the mid 1930s under the 1901 Immigration Restriction Act. His sponsorship required him to work for his sponsor - Mavis Pratt's father, J.J. Lowe. He has, on a number of occasions, shared his memories of these experiences. ${ }^{22}$ The essence is captured in this quotation:

He [J.J. Lowe] treated us [Arthur and his father] very badly, being rich. I remember once he was scolding us that we were village pigs and [had] no roots in Australia... he treated us virtually like slaves, I would say - I would use that word. And he was very strict, very stern. Even up to this day I shudder at the thought of him watching me sweeping the floor, watering the bare floor with a watering can and if the water was not properly sprinkled he would go crook saying that the dust would rise and he even watched me how I used a broom and so on and so forth.

Gee... those were dreadful days, l'd fear the daybreak over the window. I would say to myself 'Here is another day coming where I have to be scolded by the boss and looked down at as a servant by him'. ${ }^{23}$

By contrast, Mavis Pratt has quite a different emphasis: 
Then he [my father, J.J. Lowe] brought Sam [Arthur Gar-Lock Chang] out and he was a bloody nuisance. We had to get rid of him. He was a cook's son. We had to get rid of him because he was a troublemaker... He thought he owned the bloody place. He used to rule the roost and everything else... He came here not long ago... And he was running around taking photos and telling everybody that he did this and did that, and they had to leave here and everything else. And I said... 'Just take him out of here... he's nothing but a troublemaker'. ${ }^{24}$

Wing Hing Long, like the District Six Museum, illustrates how local and community museums are assimilating the different memories and views of the past, and indeed the present and future, which ebb around their spaces and their objects. They are confronting and tackling the growing acceptance that, if museums are to serve their communities well and are to act effectively as spaces for shared and challenging memories, then they need somehow to incorporate the complexities and even the contradictions and inconsistencies of the experiences and memories of different individuals and groups within those communities.

\section{COLLECTORS AND COLLECTING}

There are, however, memories and experiences other than those of curators, communities and their critics which shape and influence the tone and texture of museums and the messages they convey. These are the memories and memorialising of founding collectors, their collections and museum practices. As illustrations, I turn to four museums in Armidale in regional New South Wales.

\section{MUSEUM OF ANTIQUITIES, UNIVERSITY OF NEW ENGLAND}

The first example is an obvious one. You are reading a version of the seventh annual Maurice Kelly public lecture. This annual event is an extension activity of the Museum of Antiquities. It is an overt and public acknowledgement - or memory - of the contribution Maurice Kelly made to the establishment of the museum in 1959 and to its subsequent development. The experience is also an invitation to remember - and hopefully visit - the museum and to remember that it is a museum bound partly by its own memories and origins. Let me highlight three features.

Firstly, the Museum of Antiquities was established at a time of hope, expansion and resources for universities - the existence, extent and significance of the collection is a reminder of this period of hope and resources. The museum's subsequent survival and growth is testament to the dedication of its volunteer supporters as hope and resources disappeared. ${ }^{25}$

Secondly, the museum was established at a time when museums placed an emphasis on objects of and for themselves and it is an emphasis which is still evident in the ordered and thematic displays of well documented and didactically 
labelled objects. It is perhaps a style of presentation losing favour in a museum environment increasingly being urged to offer multiple voices and memories, entertain, challenge and provide interactivity. As such, the museum itself becomes a place to remember and to appreciate the order and the clear and unquestioned sense of purpose of this particular museum and the museum tradition which it represents.

Thirdly, the Museum is shaped by its primary purposes as a research and teaching collection and a collection which can reach out to its surrounding community. ${ }^{26}$ Hence, today, extension activities include the Maurice Kelly Lecture, the Charles Ede Prize for a student essay focusing on aspects of the museum's collection, education packages for school students, a computer database and the online access to information about the collection and its exhibitions. ${ }^{27}$ Its continuing existence is perhaps contingent on proof that the museum does contribute to teaching, research and community involvement.

\section{MUSEUM OF EDUCATION, UNIVERSITY OF NEW ENGLAND}

This idea of a museum memorialising its founders and their museum practices, and these memories influencing the current shape and tone of a museum, is also evident in two other collections and museums in Armidale. Both these collections had their origins with the Armidale Teachers' College which subsequently became the University of New England.

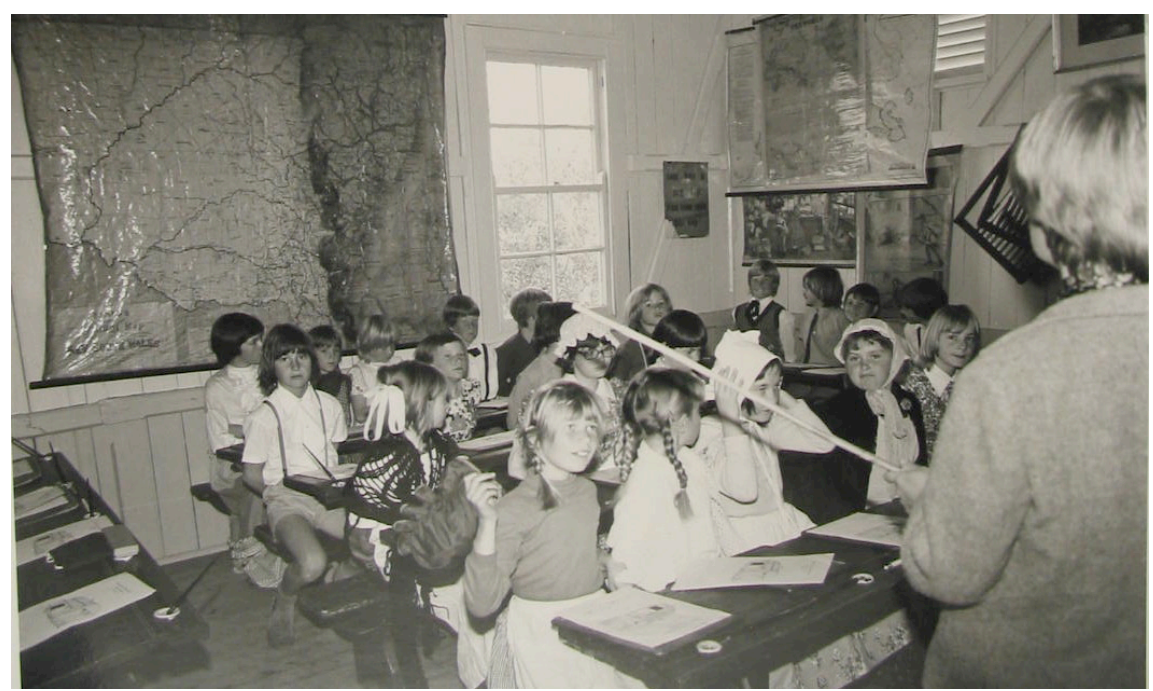

Visit to the Museum of Education, University of New England, c1980 (Photograph courtesy of the Museum)

The first of these is the Museum of Education. It was an initiative of Eric Dunlop, a lecturer in history at the Armidale Teachers' College. Dunlop was also instrumental at about the same time in seeing the revitalisation of the Armidale Folk Museum. His contribution there is recognised in the brochures about the Museum and in the portrait hanging in the front room of the museum. 
As a teacher of trainee teachers, Dunlop demonstrated a strong belief in what he termed the 'multi-sensory appeal'. He believed that students gained a greater appreciation of the past if they could handle objects, visit or at least imagine past interiors and the activities which took place there and explore the sites of historical events. ${ }^{28} \mathrm{He}$ was an early proponent of what we now call public or applied history: he wanted his students and, ultimately, teachers to take history into their communities and to bring their communities' histories into the classroom.

The establishment of the Museum of Education was an expression of Dunlop's philosophy of teaching. The first stage - the relocated 1884 Pallamallawa school building - was opened in September 1956 by the then Director General of Education in NSW, H.S. Wyndham. In explaining the museum, a brochure observed that the reconstruction of the classroom within the building was 'intended to look like an 1884 classroom'. ${ }^{29}$ Its use was for school and college students to experience what it was like to sit at the narrow desks, write on slates, and learn under the disciplinary gaze of a nineteenth-century school teacher. This hands-on experience with its emphasis on interactivity became a central tenet of the way the museum was set up and used. ${ }^{30}$ There are still the spaces where visitors can slip into a moment from the past - albeit one that is sanitised and safe. The museum offers both memories of past classroom practices and the concepts behind why the museum was established in the first place.

The Museum of Education also offers memories of another museum practice. The Museum consists of relocated buildings. The old Pallamallawa School building was moved to the college grounds in 1956 and then, in 1975, it was relocated to its current site along with a 1948 portable schoolroom from Armidale High School. In 1979, the Dumaresq School building was added to the complex. ${ }^{31}$ In the current heritage climate in which the location and curtilage of a building is seen to be as significant as the building itself, reservations are expressed about the appropriateness of relocating buildings. Yet it was a not uncommon practice in the 1960s and 1970s as local communities sought both to save buildings at risk of being demolished or falling into disrepair and to establish local museums. Relocated buildings along with relocated objects became the core of their collections and museums. The Museum of Education stands as a reminder of this practice and, perhaps, as a focus for re-evaluating the extent to which the relocation of buildings and objects alters rather than destroys the significance of those buildings and objects.

\section{Howard Hinton Collection, New England Regional Art Museum}

It is this idea of a relocated collection and the memories it captures and evokes which leads to a final example - the Howard Hinton Collection now housed in the New England Regional Art Museum. The memories here relate to memorialising and messages about the founding collector and about the collection's origins in the Armidale Teachers' College. 
Howard Hinton donated his first paintings to the College in 1929 a year after the college was opened. By the time of his death in 1948 he had sent over 1100 paintings (valued at the time at just under one million pounds, now valued at over $\$ 30$ million). His choice of the Armidale Teachers' College as the home of his collection was directed by political networks it was recommended by the then Minister for Education, David Drummond, who was also the local member of state parliament. But it became a driving force behind Hinton's vision. Not only did he want the best collection of Australian art in a regional area; he also wanted to demystify art and to encourage a broad appreciation and familiarity with Australian art. He believed that having the paintings on the walls of the Armidale Teachers' College, would imbue trainee teachers with an understanding and appreciation of art which they would carry with them into classrooms across the state. Perhaps Hinton's sentiments influenced the later practices of Eric Dunlop. Hinton is quoted as saying:

My object was to provide a complete collection illustrating the development of Australian art from 1880 onwards, and my action in making the gift to Armidale Teachers' College was prompted by my great interest in Australian education and my desire that the collections should be available in perpetuity for succeeding generations of students. ${ }^{32}$

If the memories of alumni of the Armidale Teachers' College are any indication, Hinton achieved this, at least to some extent. Tellingly, these memories - shared as alumni visit the collection in its new home - focus on both particular works and on the experience as a whole. ${ }^{33}$ Some remember

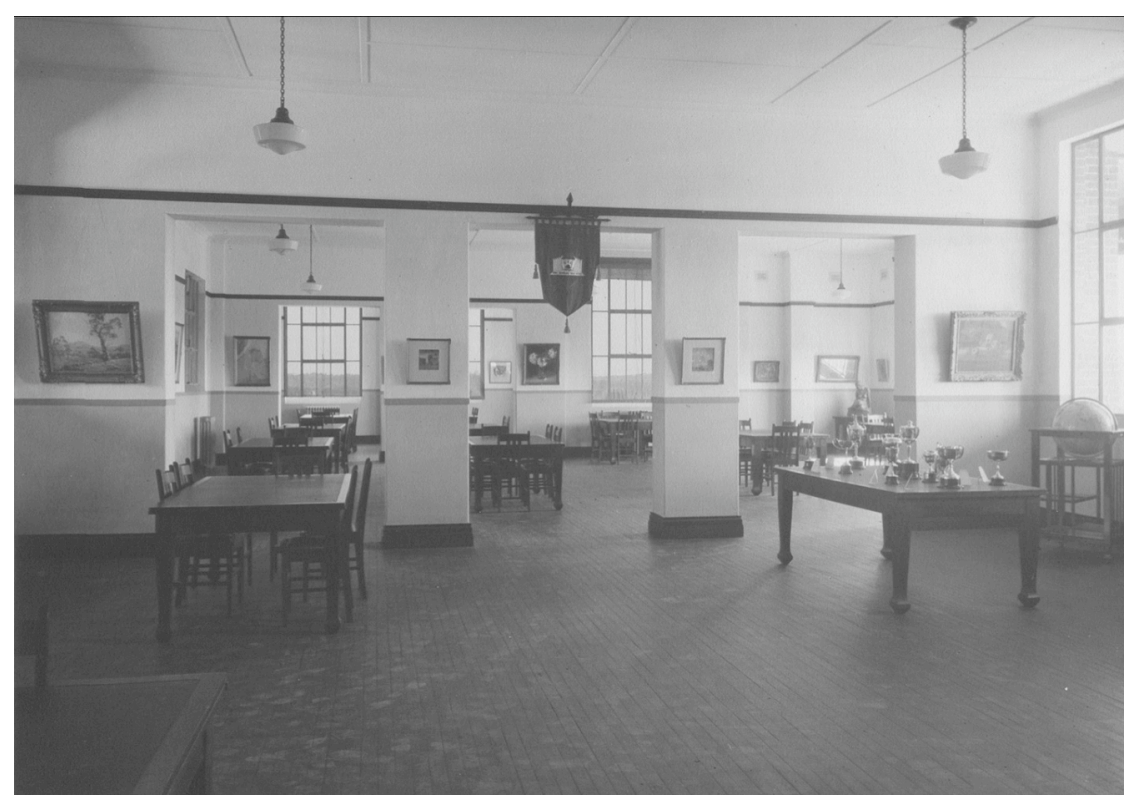

Works from the Hinton Collection in library of the Armidale Teachers' College, c1934 (Historical Resources Centre Collection, University of New England and Regional Archives) 
details: which rooms held the Norman Lindsay paintings, the yellow gloves and ash on the cigarette in the painting Yellow Gloves (although the artist's name is rarely remembered), Julian Ashton's The Awakening because it hung in the downstairs corridor next to the stained glass windows and was an arresting and large work. Other alumni simply remember that the paintings were there. Some took them so much for granted that they did not really look at them or remember them as individual items but, rather, just as 'those paintings', the Hinton paintings. Among the alumni there are also some who do state that they came to appreciate art and, subsequently, included visits to galleries as part of their lifestyles because they were nurtured during their teacher training in an environment which had a smorgasbord of paintings on the walls.

Through his collection Hinton is remembered, and so, too, are the motives behind his choice of home for his collection: the emphasis on education and on the idea that art is not for an elite but for the appreciation and edification of everyone. In its new home at New England Regional Art Museum the Hinton credo continues to direct activities. Education, travelling exhibitions and free entry are all part of the ways in which memories of Hinton have shaped and influenced museum practices there. ${ }^{34}$ They also constrain the museum's activities in some ways: there are always in the visitors' book requests for more Hinton works to be on show, yet visitor numbers indicate that the public wants the new and the innovative as well as (sometimes more than) the comfort and familiarity of the Hinton treasures.

\section{VISITOR MEMORIES}

All the museums I have mentioned are public spaces and they are all spaces which I remember visiting - they are part of my memories of museums. They exist partly for the sake of their collections, exhibitions, research and teaching. But, ultimately, and in an era when visitor numbers are seen as an indication of a museum's usefulness and viability, visitors are an essential element.

Museums want visitors to view their exhibitions and collections, take part in their activities, be stimulated, perhaps challenged, entertained and, as importantly, to take away memories which will entice them to make return visits and to regard museums as an integral part of our social, cultural and educational experiences and lives. ${ }^{35}$ In this context it is appropriate to ask what constitutes memorable moments for museum visitors and what those memories reveal about the place of museums in our lives and thinking. This, indeed, is the first exercise requested from students who enrol in my History and Museums unit. They are asked to stop, reflect, recall and share a memorable museum moment. The responses from those students enrolled during 2003 fall into a range of categories.

There are those students whose memorable museum moment is directly related to a personal association. One student discovered her local museum had an oral history interview with her grandmother. Another revisited memories of his 
childhood suburban backyard triggered by the exhibition of Hills Hoists at the National Museum of Australia. A third student remembered his childhood experiences of the Newcastle earthquake when visiting an exhibition at the Newcastle Regional Museum about the event and its impact. Yet another was moved by the story of a particular Polish immigrant presented in the Ellis Island Museum in New York and the way it made her remember and appreciate her mother's stories of being a child migrant. In these personal associations emotions, recollections of moments in one's own life and memories of lost places all play a part. The museum becomes what Gaynor Kavanagh has described as a dream space. As she observes:

In dream space, many things might tumble through our minds: bits of songs, half-written shopping lists, things left unsaid. The shape or shadow of something, its texture or colour, the operation of space and people moving through it can be triggers to an endless range of personal associations... We have to accept more fully the imagination, emotions, senses and memories as vital components of the experience of museums. ${ }^{36}$

Another group of students recall being overwhelmed by a precious or significant object, although the experience was invariably prefaced with some knowledge or expectation on the part of the visitor. Tellingly in this category, for our ancient historians, there are a number of mummified bodies. In explaining her excitement at viewing Tutankhamun's mummy in the Cairo Museum, one student wrote:

Since my first encounter with an Egyptian mummy at the Australian Museum in Sydney in the late 1960s, I have always held a fascination for all things Egyptian. To my childhood self, that obscure, roughly human shape covered in grimy bandages represented another world of exotic, intangible being. High school ancient history lessons, television documentaries and news of archaeological finds kept my interest simmering along until I could one day immerse myself in the real thing. That opportunity finally arose in September 1985.

A third category of memorable moments focused on encountering the unexpected and learning from the encounter. One student recalled her visit to an exhibition at the State Library of NSW expecting only documents and discovering objects. Another was surprised to discover that the Crown Jewels in the Tower of London consisted of a roomful of precious objects and not just a crown and sceptre. Another recorded his delight at discovering, on a visit to the Norman Lindsay Museum at Springwood, the range of work Lindsay did and encountering 
the processes involved in producing his work. As this student observed, prior to the visit his image of Lindsay was as

a water colour artist who favoured nudes in fantastic settings as a subject. I also knew that he led some sort of bohemian life in a country area near Sydney but I knew little else about him.

The visit changed his knowledge and appreciation of the artist and his contribution.

A fourth category of students' memorable museum moments emphasises the social nature of a particular museum visit, a visit accompanied by a sister, by husband and children, by children who enjoyed the interactive moments, by the pleasantness of museum staff and other visitors. The museum visit becomes an outing and a leisure activity. As one student concluded after describing a day visiting the recreated HMS Endeavour:

Perhaps it was the beautiful day, our interest in sailing and all things nautical, the mood of the other visitors, the cheerful staff and the feeling of stepping back in time that made my visit... one that has stayed in my mind.

A fifth category of memorable moments focused on having the opportunity to touch, hear, or do something as opposed to reading and viewing. For one student this entailed going for a sail in the boat. For another it was the pleasure of pressing the button on a lighthouse light and watch it illuminate the rest of the exhibition.

A further category focused on the difficulties and frustrations experienced in a particular museum visit: long queues, having to pay an entrance fee, crowded blockbuster exhibitions, discovering that a museum knew nothing about its founder.

These patterns and memories echo the patterns in the small number of studies done of individuals' memories of their visits to museums. ${ }^{37}$ They also resonate with my own memories of museum visits. These consist of the sorts of encounters with the different museum practices described in this article but they also consist of memories about moments of contemplation and emotion. Among my many memories are those of being overawed, for example, by the beauty and artistic skill of Robert Klippel sculptures; being overwhelmed with emotion in the Apartheid Museum in South Africa and on Robben Island; and being delighted by watching our children engage with a particular museum activity or moment. As the student in the History and Museums unit whose memorable museum moment focused on Ellis Island so aptly observed: 
Any museum can say it is successful if each visitor takes away a memory, vision or new piece of wisdom or, like Ellis Island does, reach the inner senses.

Do any of these memories resonate with your museum experiences? Indeed, let me ask you the same questions l've asked my students: 'What is your most memorable museum moment? Why was it memorable? How does the memory reflect your view of the role and place of museums in our society?'. If you haven't visited a museum recently, ask yourself why. Perhaps also ask whether your expectations of museums are being met. Indeed, in what ways do our very personal, reflective and eclectic memories gell with what it is that the museums their creators, curators, sponsors - want us to remember? Ask whether we, as museum visitors and members of the public, should and can add our memories to those being collected, represented and catered for? And if we should, how can our diverse and individual memories be incorporated? What stories do they tell? What memories do they share?

\section{CONCLUSION}

So I come full circle and return to the quotation from Tessa Morris-Suzuki and to the idea that while debates continue - and must continue - about the nature and place of national remembering in museums, we also need to leave spaces for the diversity and complexities of other relationships between museums and the many memories which can be represented, encountered and created within and around them. There is a need to create spaces for misremembering as well as remembering; for mistakes and corrections; for different and often conflicting memories about an object, place, person, or experience; for the memories and memorialising of collectors and their collections and of past and present museum practices; and for the place and resonance of visitor memories.

Will these spaces increasingly also be created and shaped through the emergence of virtual museums and virtual memories? New technologies among other things offer ways to layer information and ideas, to scatter them, to reconnected them in many different ways, to evoke and present many different memories, offering new and different ways to invite relationships between museums and memory.

\section{ENDNOTES}

\footnotetext{
${ }^{1}$ The article is based on my address delivered as the seventh Annual Maurice Kelly lecture in September 2003. It draws on my life as a museum junkie but I am indebted to a number of people for providing insights and images while acknowledging that its final shape and any of its oddities are mine. In particular I wish to thank the University of New England Curator, Nicole McLennan; Curator of the Armidale Folk Museum, Peter Chambers; Greg Horsley and Denis Wright from the Museum of Antiquities Committee; the Director of NERAM - and my partner in life, Joe Eisenberg; and students in my History and Museums unit. ${ }^{2}$ See, for example, Susan Crane (ed), Museums and Memory, Stanford University Press, Stanford, 2000; Paul Hamilton, 'Memory studies and cultural history', in Hsu-Ming Teo and Richard White (eds), Cultural History in Australia, University of NSW Press, Sydney, 2003, pp81-97; Chris Healy, 'Histories and
} 
collecting: museums, objects and memories', in Kate Darian-Smith and Paula Hamilton (eds), Memory and History in Twentieth Century Australia, Oxford University Press, Sydney, 1994, pp33-51.

${ }^{3}$ See, for example, Simon Knell (ed), Museums and the Future of Collecting, Ashgate, Aldershot, 1999.

${ }^{4}$ See, for example, Flora S. Kaplan (ed), Museums and the Making of 'Ourselves': The role of objects in national identity, Leicester University Press, Leicester, 1994; Graeme Davison, 'Museums and national identity', Paper to the Museums Australia National Conference, 2003.

http://www.museumsaustralia.org.au/events.htm; and Roslyn Russell, 'Once upon our times', Museum National, vol 10, no 4, 2002, pp5-7.

${ }^{5} \mathrm{An}$ introduction to this debate and its broader context is provided in Bain Attwood and S.G. Foster (eds), Frontier Conflict: The Australian Experience, National Museum of Australia, Canberra, 2003.

${ }^{6}$ Tessa Morris-Suzuki, 'Sakhalin: on the frontiers of memory', Meanjin, vol 57, no 3,1998, p.540.

${ }^{7}$ The Golden Threads Project has produced a travelling exhibition, a website (amol.org.au/goldenthreads) and a book: Janis Wilton, Golden Threads: the Chinese in regional NSW 1850-1950, Powerhouse Publishing, Sydney, 2004.

${ }^{8}$ Priscilla Wegars, 'How museums can attract and involve audiences of Asian ancestry'. Notes provided at a public lecture given in 2000 at the Powerhouse Museum in Sydney, especially pp5-8.

${ }^{9}$ Alessandro Portelli, The death of Luigi Trastulli and other stories, State University Press of New York, Albany, 1991, pp1-28.

${ }^{10}$ For a more detailed version of this argument see Janis Wilton, 'Objects and their stories', Golden Threads Stories, amol.org.au/goldenthreads, 2000.

${ }^{11}$ Two further sites have since opened - one in Maryland and one in Washington. Visit the museum website at www.nmai.si.edu.

${ }^{12}$ Gustav Heye (1874-1957) was the wealthy New Yorker who bequeathed the collection.

${ }^{13}$ W. Richard West, 'Overview', Native Peoples, vol 8, no 1, 1994, p26.

${ }^{14}$ Quoted in Dan Argent, 'All roads are good', Native Peoples, vol 8, no 1, 1994, pp45-46.

${ }^{15}$ Holland Cotter, 'New museum celebrating American Indian voices', New York Times, 28 October 1994, pC14.

${ }^{16}$ Visit the museum website at www.africanart.org/index.htm

${ }^{17}$ Robert Smith, 'Art in review', New York Times, 28 October 1994, pC24.

${ }^{18}$ District Six was a working-class, poor area of Cape Town which, until 1966, was home to a wide range of South Africans from different cultural and religious backgrounds. Under apartheid, it was declared a 'whites only' area and between 1966 and 1981 residents were forcibly relocated and scattered and buildings demolished. For a history of the district and its museum see Ciraj Rassool and Sandra Prosalendis (eds), Recallling Community in Cape Town: Creating and Curating the District Six Museum, District Six Museum, Cape Town, 2000.

${ }^{19}$ This is one of the central arguments in the detailed and engaging article by Charmaine McEachern, 'Working with memory: the District Six Museum in the new South Africa', Social Analysis, vol 42, no 2, 1998, pp48-72.

${ }^{20}$ For a more detailed introduction to the history, stories, objects and buildings of Wing Hing Long see Janis Wilton, 'Wing Hing Long: from store to museum', Golden Threads Stories, amol.org.au/goldenthreads/stories/whl.asp, 2000.

${ }^{21}$ This section summarises points raised in Janis Wilton, 'The walls speak, don't they? Heritage places and contested memories: a case study', Oral History Association of Australia Journal, no 22, 2000, pp16-23.

${ }^{22}$ See, for example, Karl Zhao, 'Memories of a difficult past', History, Magazine of the Royal Australian Historical Society, March 2000, pp10-11.

${ }^{23}$ Arthur Gar-Lock Chang interviewed by Ann Turner, 1991, Australian National Library Oral History Collection, TRC 2724, transcript p8.

${ }^{24}$ Mavis Pratt interviewed by Joe Eisenberg and Janis Wilton, February 1998.

${ }^{25}$ G.H.R. Horsley, 'From Classics Museum to Museum of Antiquities: some trajectories' in J.S. Ryan (ed),

The Arts from New England: University Provisions and Outreach 1928 to 1998, University of New England, Armidale, 1998, pp301-311.

${ }^{26}$ ibid, p306.

${ }^{27}$ Visit the museum and/or its website www.une.edu.au/arts/Museum

${ }^{28}$ See, for example, E.W. Dunlop, 'History through museums', Paper to Australian UNESCO Seminar, undated, Historical Resources Centre Collection, University of New England and Regional Archives. 
${ }^{29}$ Armidale Teacher's College Museum of Education, information sheet, undated (late 1950s?), Historical Resources Centre Collection, University of New England and Regional Archives.

${ }^{30}$ See, for example, 'Recalling past classes at the CAE Museum of Education', press clipping, December 1988, Historical Resources Centre Collection, University of New England and Regional Archives.

${ }^{31}$ Museum of Education, information brochure, 1976/1977, Historical Resources Centre Collection, University of New England and Regional Archives. See also the museum website

(www,une.edu.au/archives/museumhist.html) and Dinah Kennedy, 'Where school becomes a thing of the past', Northern Magazine, 21 November 1976, p3.

${ }^{32}$ Quoted in A Memorial Volume to Howard Hinton, Angus and Robertson, Sydney, 1951, p6.

${ }^{33} \mathrm{I}$ am indebted to Joe Eisenberg, Director of NERAM, for providing these examples and observations.

${ }^{34}$ Visit the museum and/or its website: www.neram.com.au

${ }^{35}$ There is an increasing body of literature which explores how to attract, engage and sustain visitor numbers and interest. See, for example, James A. Bradburne, 'A new strategic approach to the museum and its relationship to society', Museum Management and Curatorship, vol 19, no 1, 2001, pp75-84.

${ }^{36}$ Gaynor Kavanagh, Dream Spaces: Memory and the Museum, Leicester University Press, London, 2000, p3.

${ }^{37}$ See, for example, Alan Radley, 'Boredom, fascination and mortality: reflections upon the experience of museum visiting', in Gaynor Kavanagh (ed), Museum Languages: Objects and Texts, Leicester University Press, London, 1991, pp63-83; and Kavanagh, Dream Spaces, op cit, pp148-156. 